مقالم برأوهشى

تاثير آلودكى هاى صوتى تك فركانس بر روى رشد باكترى اشيرشياكلى

\author{
محمدامين يونسى هروى'"، سيد /مين حسينى'، رضا بشارتى" \\ ' كارشناس ارشد مهندسى يزشكى، كروه علوم بايه يزشكى، دانشكاه علوم يزشكى خراسان شمالى، بجنورد، ايران

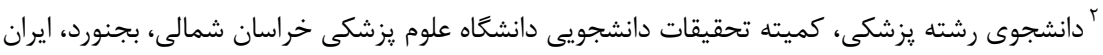

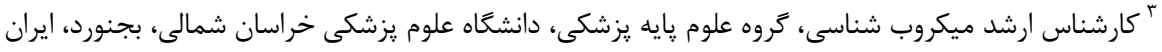

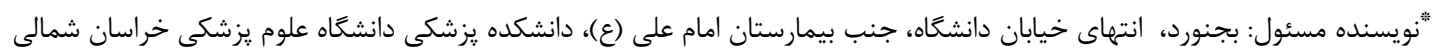 \\ a.younessi7@gmail.com: بـت الكترونيان \\ وصول:
}

جكيده

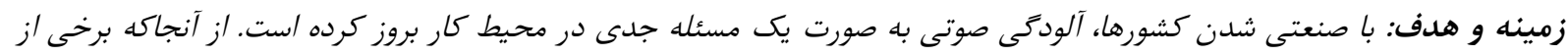

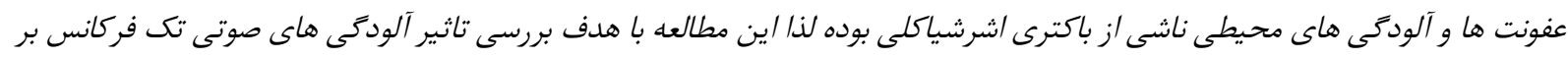

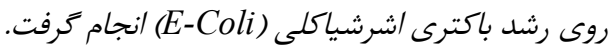



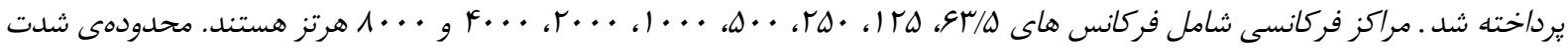

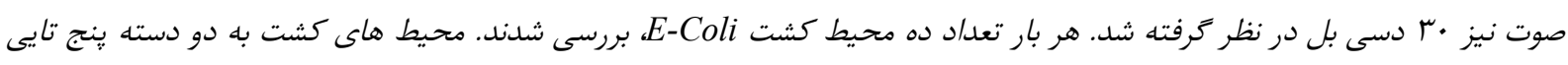

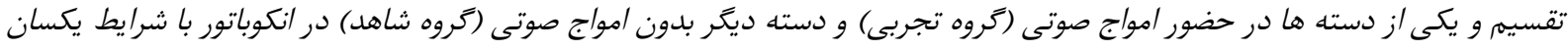

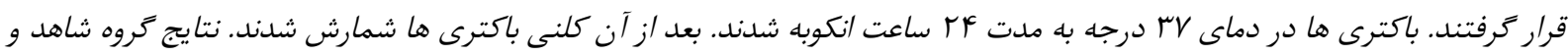

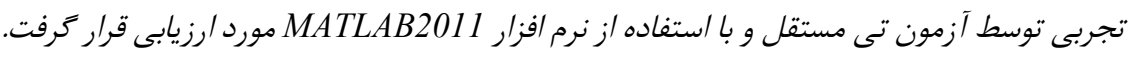

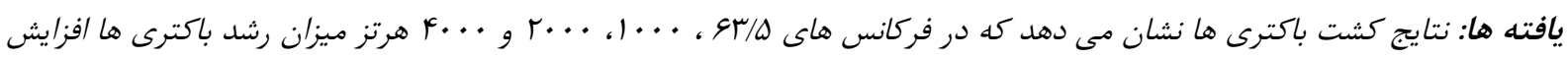

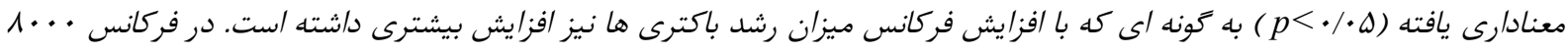

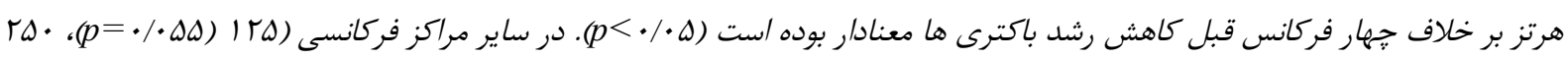



مشاهده نشد.

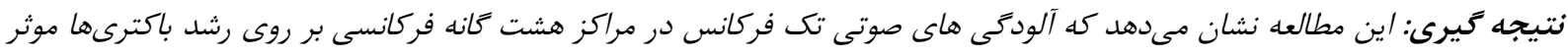

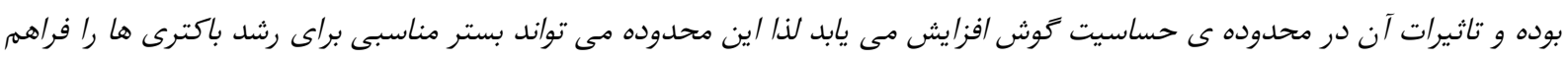

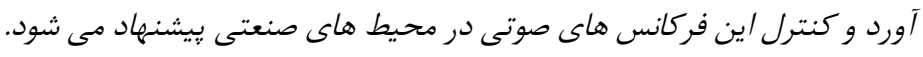

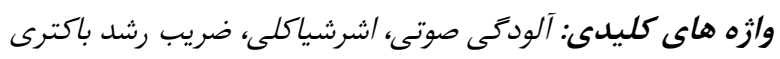

طولى بودن موج صوتى است كه باعث مرتعش كردن مقدمه اجسام خواهد شد و دومين دليل اثرات سوء اين امواج

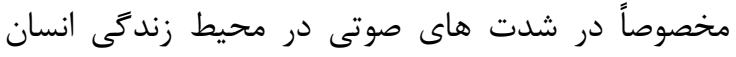
با صنعتى شدن كشورها، آلودگى صوتى به صورت يك مدار

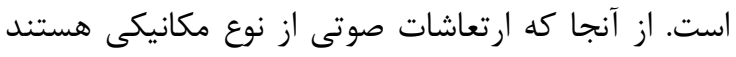

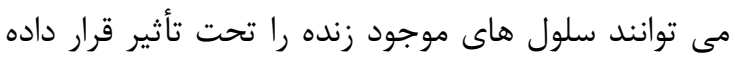
و موجب به هم ريختن محتويات سلول و تغيير رفتار آنها

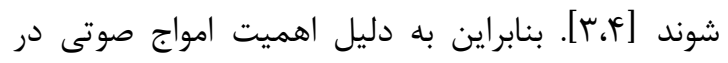
ايجاد تغييراتى در رفتار سلولى و نيز بيى بردن به به مكانيزم



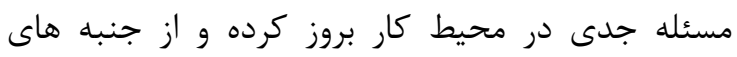

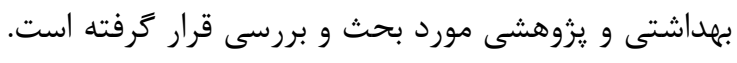
آلودگى صوتى، صدايى ناخواسته، ناخوشايند و نامطلوب

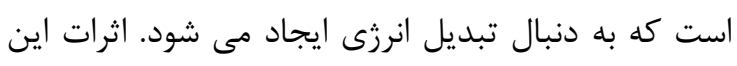

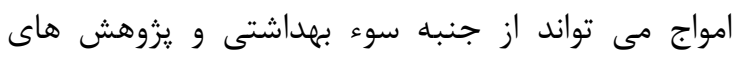

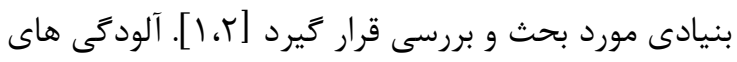
صوتى به دو علت مورد توجه هستند: دليل اول خاصيت 
فركانس هاى مختلف مورد بررسى قرار نغرفته است. همجنين به دليل تاثير بسزاى اين باكترى مخصوصا گَونه هاى بيمارى زاى آن بر روى سلامت انسان بررسى تاثير بانير

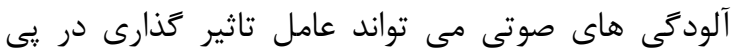
بردن به الكَى رشد اين باكترى تحت تاثير امواج صوتى لتى

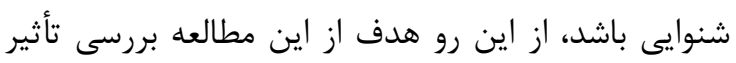

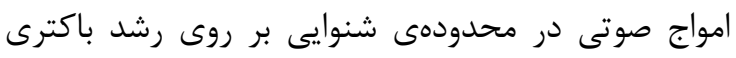
اشرشياكلى و همجنين بررسى زمان ساز كارى باكترى در درى يك محيط كشت خواهد بود. اين هدف با كشت باكترى

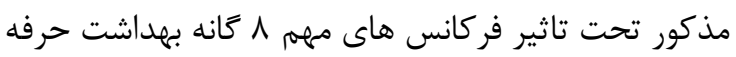
اي مورد بررسى قرار خواهد كرفت.

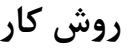

اين مطالعه به صورت تجربى با هدف بررسى تاثير امواج تك فركانس صوتى در فركانس هاى مختلف بر روى

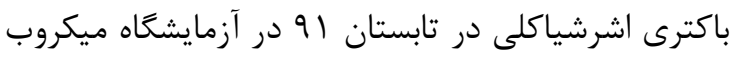

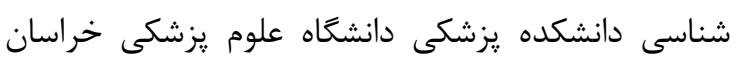
شمالى انجام شد. فر كانس هاى مختلفى كه در اين مطالعه دانس مورد بررسى قرار گرفتند، مراكز فر كانس هاى هشت كانه در بهداشت حرفه اى است كه در صنعت نقش ايفا مى كنند. اين مراكز شامل فركانس هاى هراس • •

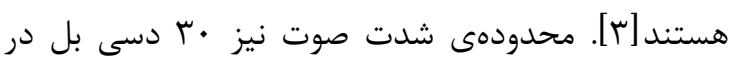

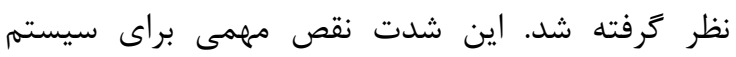
شنوايى انسان به وجود نخواهد آورد. براى توليد امواج صوتى در مراكز هشت كانه فركانسى نيازمند يك مولد

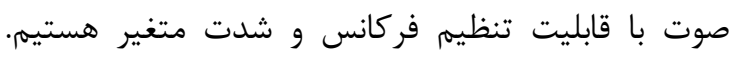

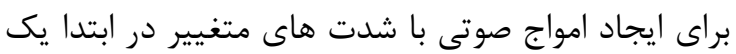

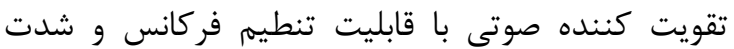

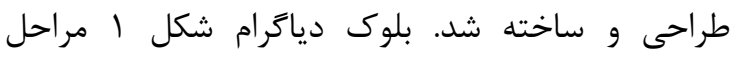
طراحى ساخت مولد صوت تك فركانس با شدات شدت هاى مختلف را نشان مى دهد. تقويت كننده صوتى طراحى مرلى

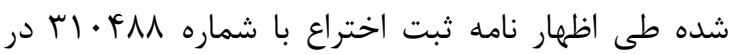
سازمان ثبت اسناد و املاك كشور ثبت شده است. جامعه مورد مطالعه محيط كشت جامد يكسان با تعداد اوليه

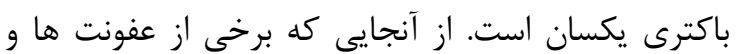

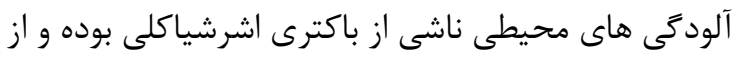

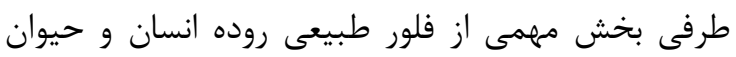

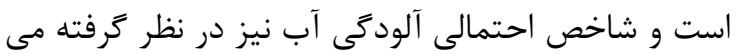



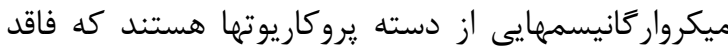
هسته سلولى مى باشند و از جمله موجوداتى هستند كه

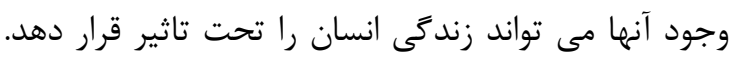
هر باكترى هنگامى كه در يك محيط جديد قرار مى نى

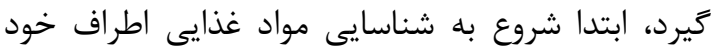

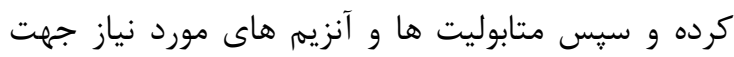
تجزيه مواد غذايى توسط سلول توليد و نهايتاً رشد سلول هرد شروع مى شود كه اين مرحله بسته به نوع محيط و نوع تران سلول و تعداد سلولهاى وارد شده به محيط كشت و و شرايط فيزيكى حاكم بر آنها، مدت زمان خاصى (زمان

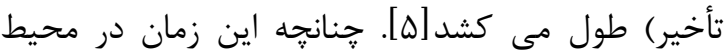
كشتى كه فقط يك ماده غذايى مانند لاكتوز وجود داشته باشد، تحت تأثير يك عامل خارجى قرار كيرد، نشانه

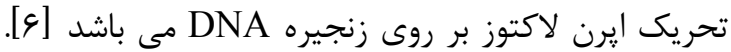

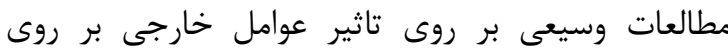

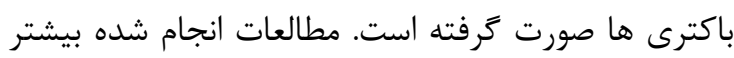
بر روى تاثير ميدان هاى مغناطيسى خارجى و امواج ماورا

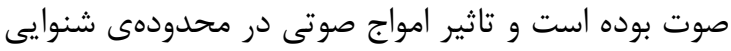


كرفته است. از آنجا كه بسيارى از عفونت ها و و آلودكى هانى هاى محيطى ناشى از باكترى اشرشيا كلى است بيشتر

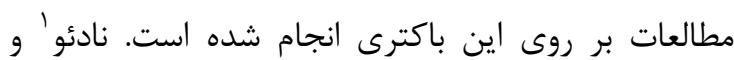



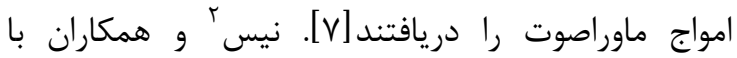
بررسى كارايى فرآيند فراصوت در كندزدائ دراضي يساب تصفيه

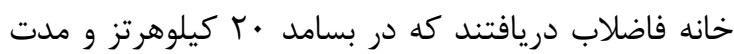
زمان •4 دقيقه حذف باكترى اشرشياكلى مشاهده مى

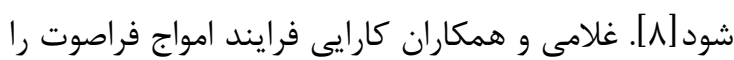

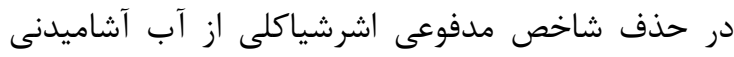

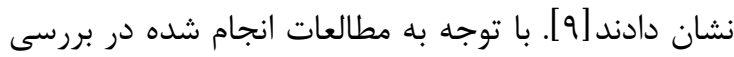
تاثير امواج خارجى بر روى رشد باكترى اشرشياكلى، توانه خاصيت ضد باكترى امواج ماوراصوت و خاصيت افزايش رئ رئرئ



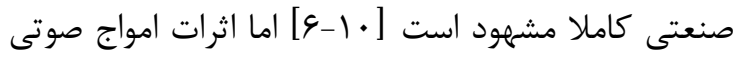

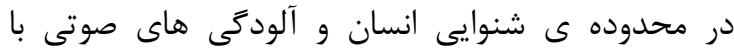


رشد باكترى ها در فركانس هاى مختلف علاوه بر درصد

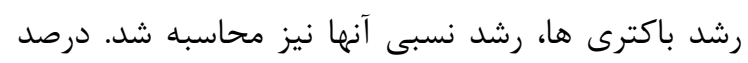



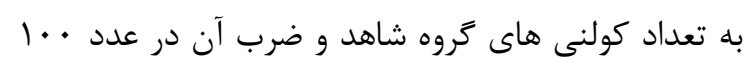

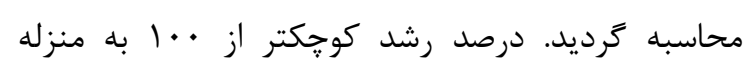

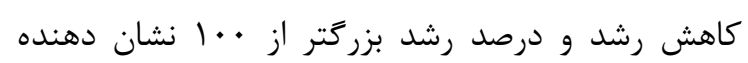

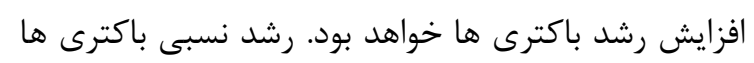

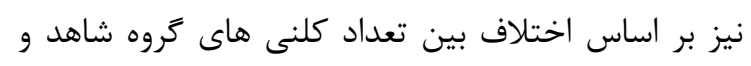

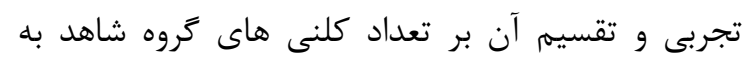

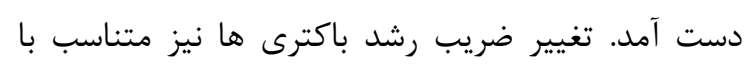

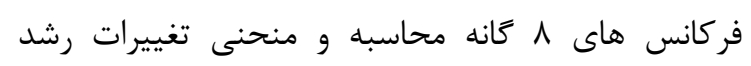
باكترى ها در فركانس هاى مختلف با استفاده از جعبه مانه



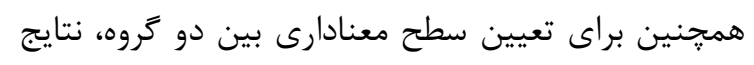
كروه شاهد و تجربى توسط آزمون تى مستقل و بـ با استفاده

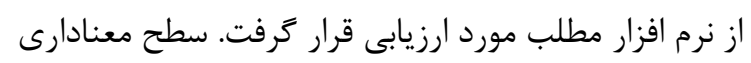

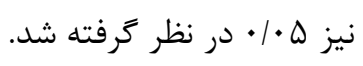

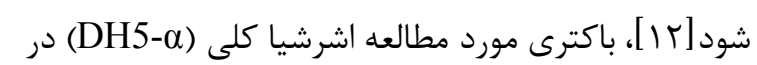

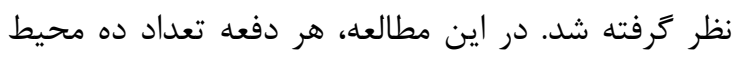

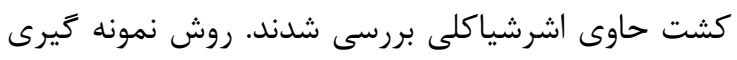

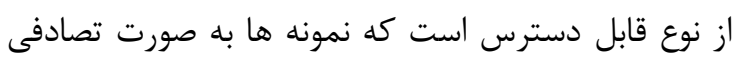

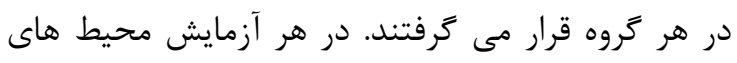

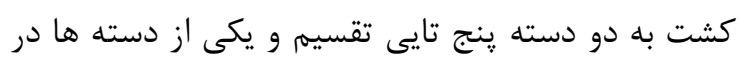

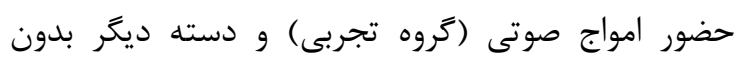
امواج صوتى (كروه شاهد) در انكوباتور با شرايط يكسان

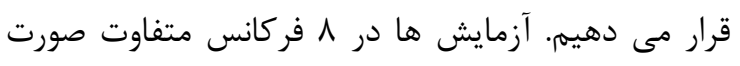

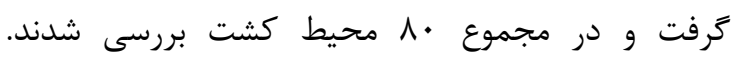

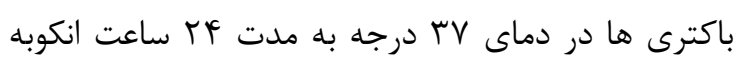

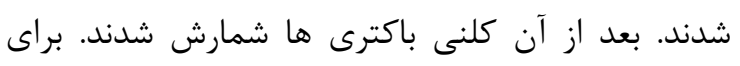

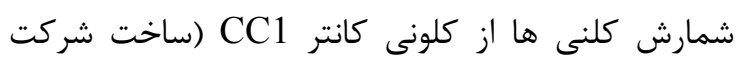

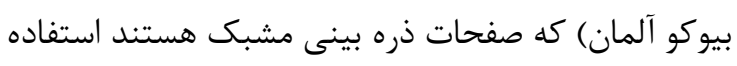

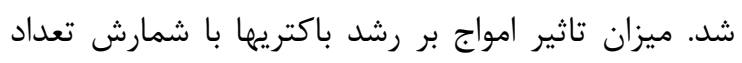

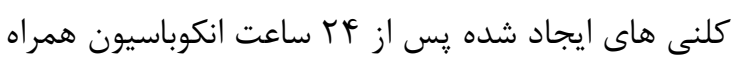

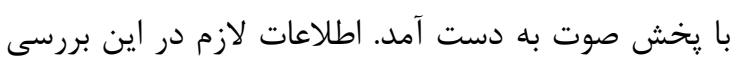


صوت سنج جمع آورى مى شد.به منظور بررسى ميزان

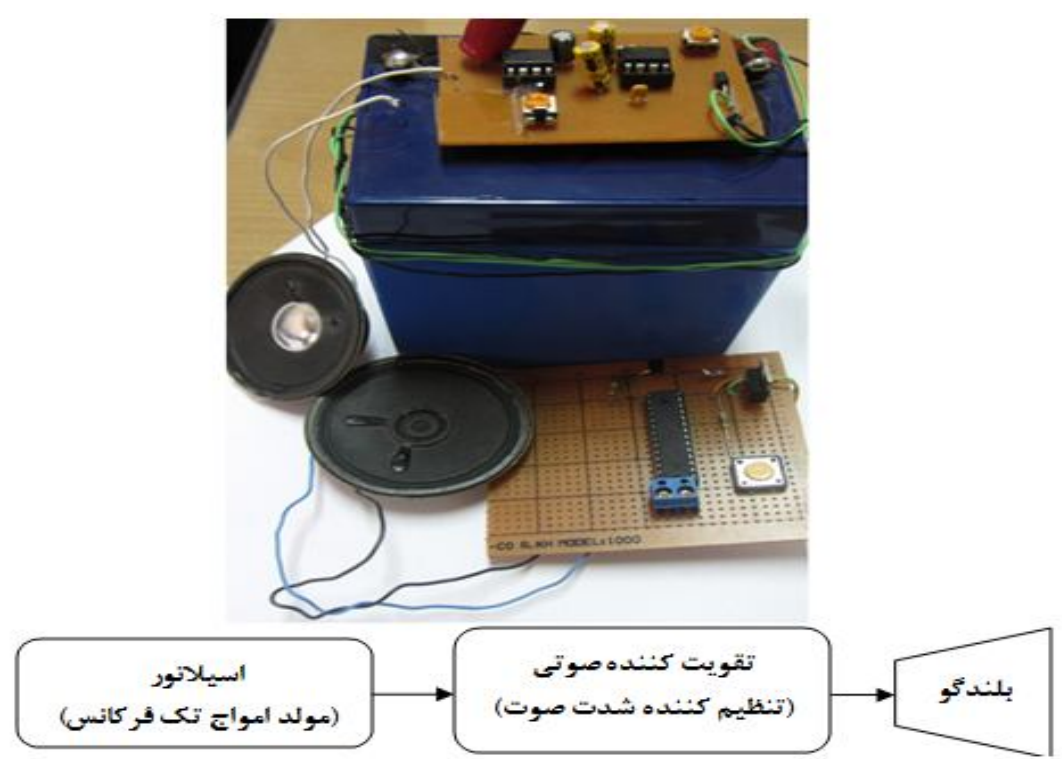

شكل ا: بلوك دياكرام اجزاء تقويت كننده ساخته شده براى توليد امواج صوتى تك فر كانس به همراه نمونه ساخته شده 
فركانس 1 كيلو هرتز معنادار است. در ساير فركانس ها افزايش رشد باكترى ها مشاهده شده است و در فر كانس در دانس

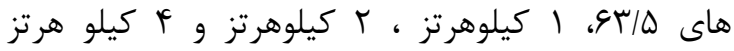

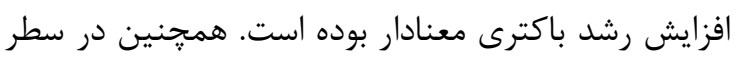
دوم جدول 1 متوسط رشد نسبى باكترى ها در فركانس هاى مختلف مشاهده مى شود. بر اين اساس در فركانس

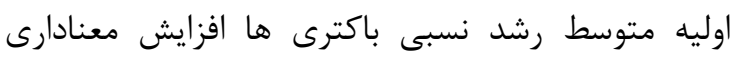

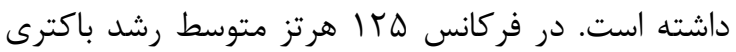

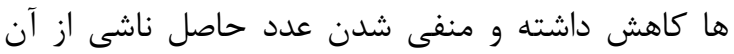

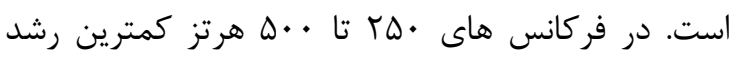
نسبى وجود داشته است و اين امر نشان دهنده عدم فرمان تغييرات رشد در اين فركانس هاست. در فركانس هاى

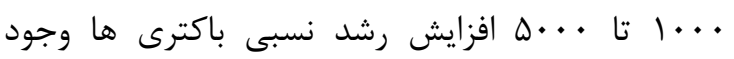
داشته و با افزايش فركانس رشد نسبى نيز بيشتر شده

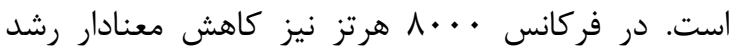

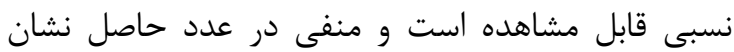

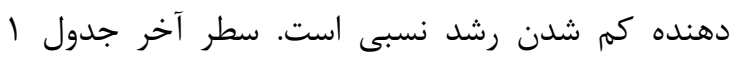
مقادير p ناشى از آزمون تى مستقل بين كروه هاى شاهد استى و كنترل در بين فركانس هاى مختلف را نشان مى دهى دهد. شكل r الكوى ضريب رشد باكترى تحت تاثير فركانس

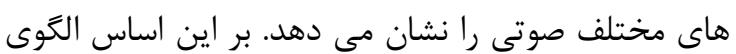
تغييرات رشد باكترى در مراكز فركانسى با يكى معادله

درجه r تخمين زده شده است.
يافته ها

با شمارش كولنى ها ميزان رشد باكترى ها تحت تاثير امواج صوتى تك فركانس مورد اريابى قرار كرفت. نتايج

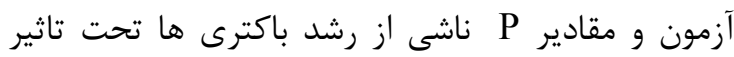

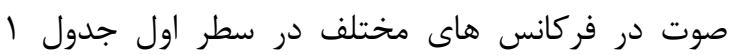
نشان داده شده است. در فركانس اوليه ه/باء هرتز تعداد كولنى ها افزايش يافته و تغييرات آن معنادار است. در دران

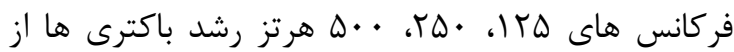
الكوى مشخصى يِيروى نكرده و تغييرات معنادار نبوده

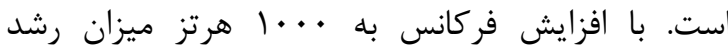
باكترى ها افزايش يافته و تغييرات آن نيز معنادار است. اين تاثير در فركانس ب و \& كيلوهرتز نيز به طور مشابيه قابل شهود بود اما ميزان افزايش رشد نسبت به فر فركانس كيلوهرتز بيشتر بوده است. در فركانس 1 كيلو هرتز نيز تغييرات رشد معنادار بوده است و ميزان رشد باكترى بان بان اعمال صوت در اين فركانس كاهش يافته است. در شكل بكل بكان

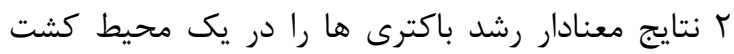
جامد و با تغيير فر كانس در تروه هاى شاهد و مورد براى يك نمونه محيط نشان مى دهد. درصد رشد باكترى ها در

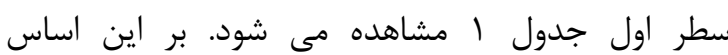

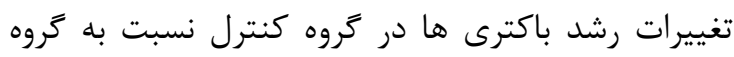



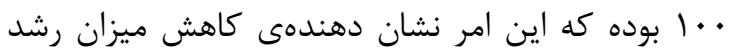

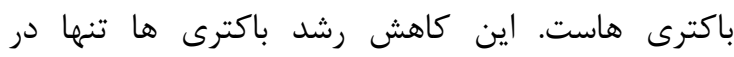

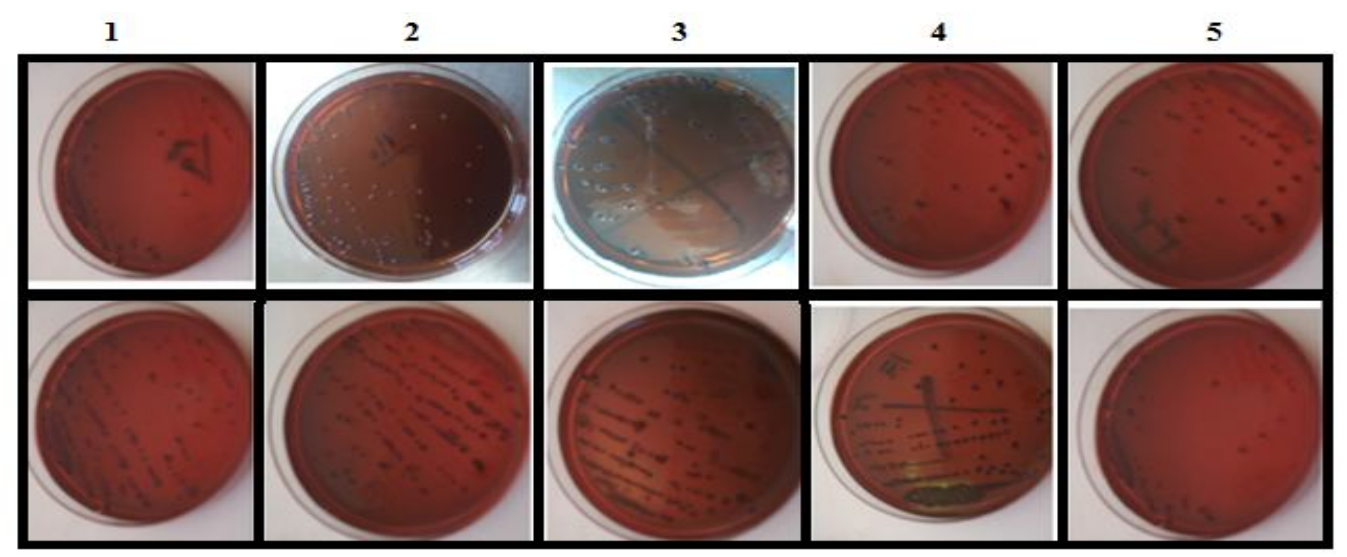

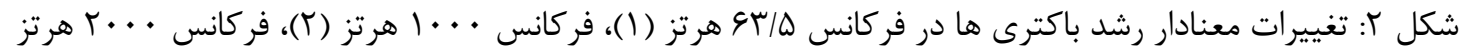

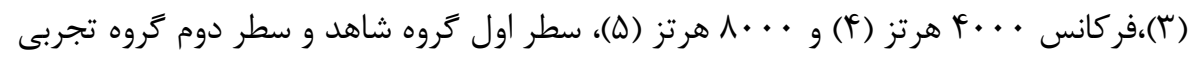




\begin{tabular}{|c|c|c|c|c|c|c|c|c|}
\hline فر كانس(هرتز) & $8 \% / 0$ & Ird & $r \Delta \cdot$ & $\Delta \cdots$ & $1 \cdots$ & $r \cdots$ & $f \ldots$ & $\wedge \cdots$ \\
\hline درصد رشد باكترى & $r \Delta r \pm q$. & $q r \pm 1 r$ & $111 \pm r \omega$ & $1 r \Delta \pm r r$ & $r \mid r \pm r r$ & $F V I \pm V$ & $\Delta r Y \pm V F$ & $r q \pm q$ \\
\hline رشد نسبى باكترى ها & $T / V$ & $-\cdot 109$ & $.1 \cdot 9$ &.$/ 15$ & $1 / \pi 1$ & $r / \Delta 9$ & $r / l r$ & $-\cdot N T$ \\
\hline Pقادير P & $\cdot / \cdot r \wedge$ & 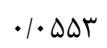 & $\cdot / \cdot \wedge 11$ & $.1 \cdot$ vef & . . मq &.$/ . r 9 \Delta$ & $\cdot|\cdot| 01$ & $\cdot \mid \cdot r q I$ \\
\hline
\end{tabular}

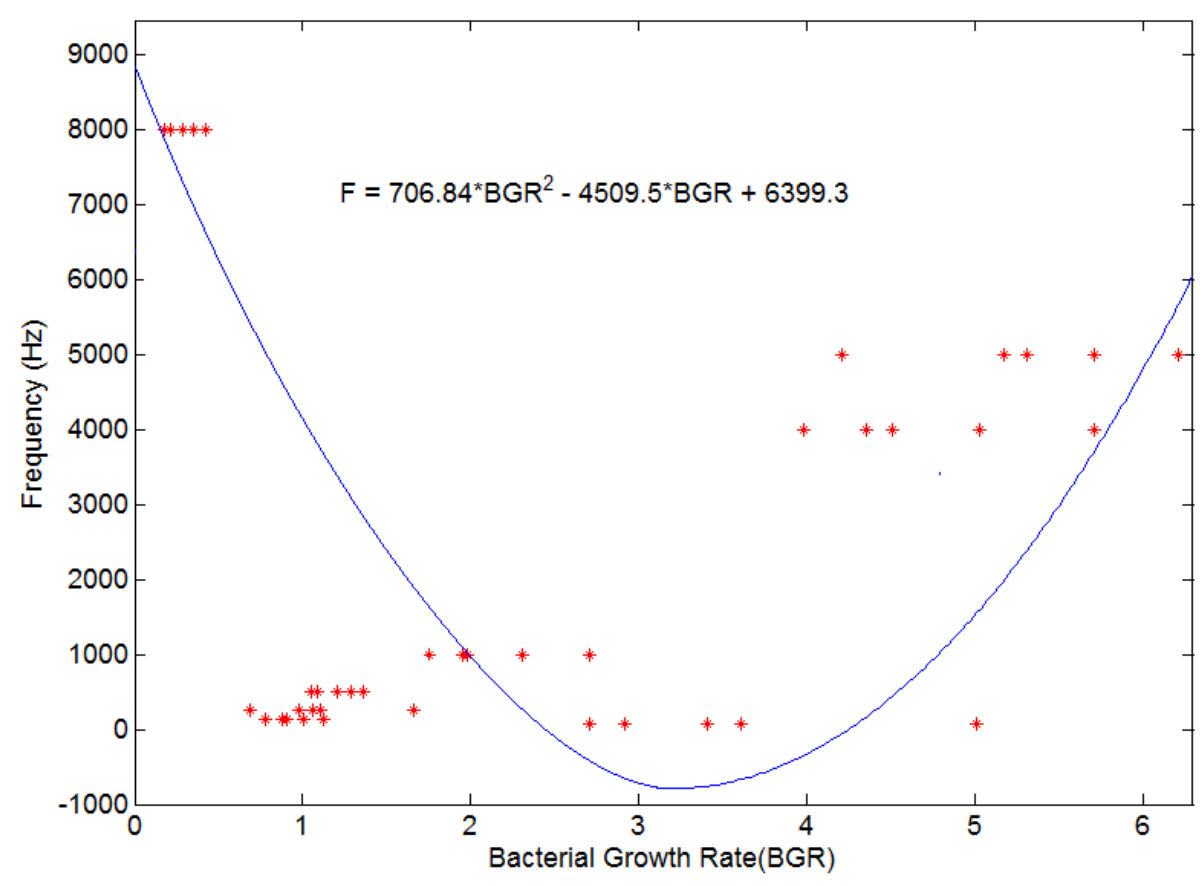

شكل گا: منحنى تغييرات ضريب رشد باكترى ها و فر كانس هاى مختلف

است. افزايش معنادار رشد باكترى ها نشان مى دهد كه با افزايش ميزان فر كانس، تغييرات افزايشى رشد باكترى نيز بيشتر خواهد شد اما اين روند افزايشى از فركانس 1 كيلو هرتز متوقف شده و ميزان رشد باكترى با اعمال صوت در اين فركانس به صورت معنادارى كاهش يافته است. مطالعات فراوانى بر روى تاثير عوامل خارجى بر رشد

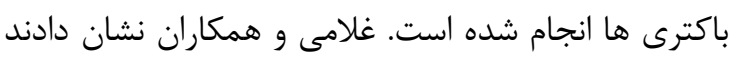
كه امواج ماوراصوت در حذف باكترى اشرشياكلى و ولى استافيلوكوكوس اورئوس موثر بوده و اين كارايى را مستقل

\section{بحث}

اين مطالعه با هدف بررسى تاثير امواج صوتى تك فركانس بر روى رشد باكترى انجام شده است. نتايج اين مطالعه نشان مى دهد كه در فركانس ف/ هاع هرتز تعداد كولنى ها به صورت معنادارى افزايش يافته است. در فر كانس هاى دهى درى

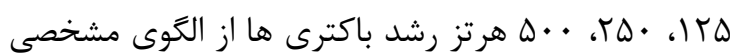

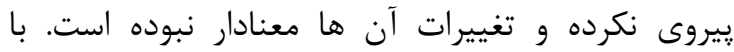
افزايش فركانس و در فركانس هاى ا، Y و أ كيلو هرتز ميزان رشد باكترى ها به صورت معنادارى افزايش يافته 
اما براى صحت اين امر توسعه ى مطالعه در شدت هاى ديخر نيز بيشنهاد مى شود.

\section{نتيجه كيرى}

در اين مطالعه به بررسى تاثير امواج صوتى تك فركانس

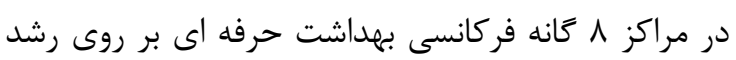
باكترى اشرشياكلى يرداخته شد. نتايج اين مطالعه نشان

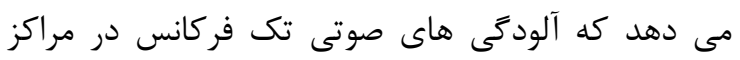

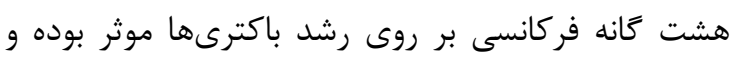

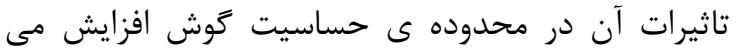



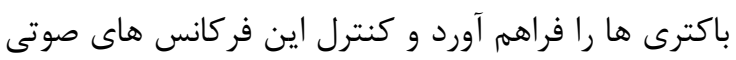
در محيط هاى صنعتى بيشنهاد مى شود.

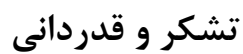
بدين ترتيب نويسند

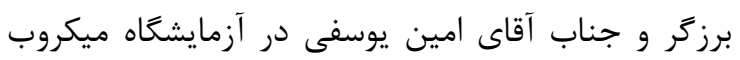



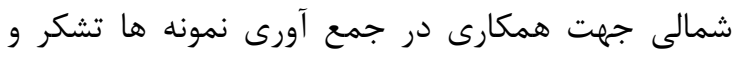

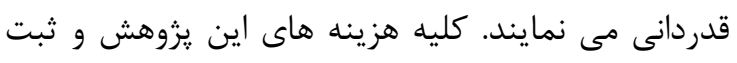

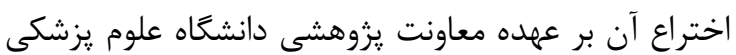

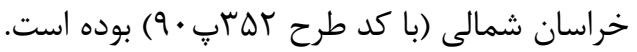

از غلظت ميكروبى دانستند [9]. آنتونياريس' و همكاران

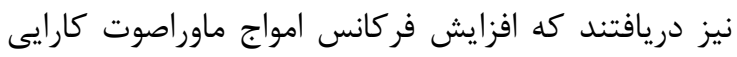

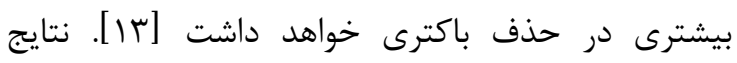
تحقيق جويس و همكاران نشان داد كه در در بسامدهاى

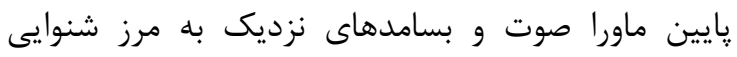



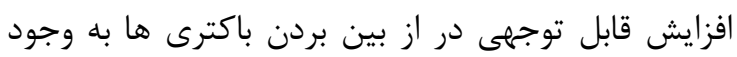

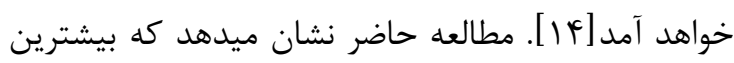
رشد معنادار باكترى ها در فركانس هاى باند ميانى

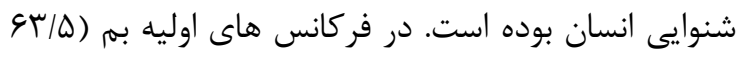

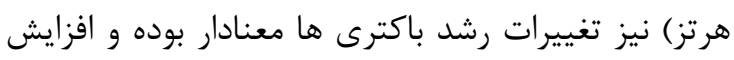
داشته است. آنجه مشهود است كاهش رشد باكترى ها در

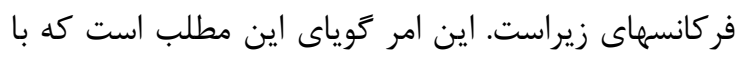

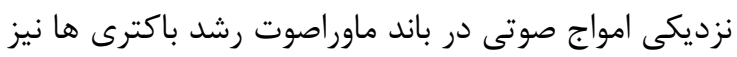

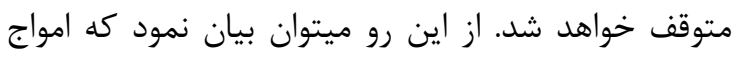

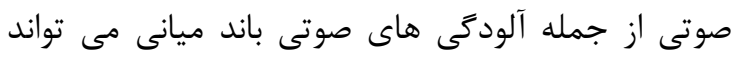
موجب افزايش فعاليت انتقالى، دهيدروزناسيون آنزيم هاى آنى

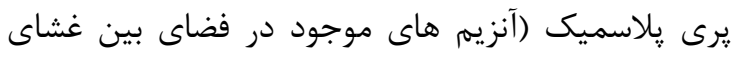
يلاسمايى و ديواره سلولى باكترى) و سرانجام تحريك دئي DNA و RNA

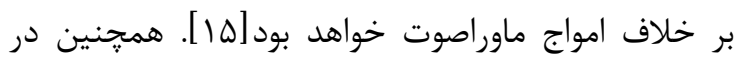
فر كانس هاى حساس گَوش اين آثار بيشترين حالت خوات خود

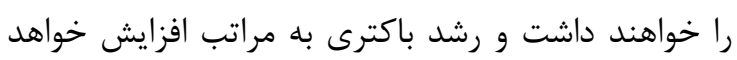

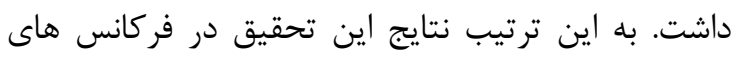

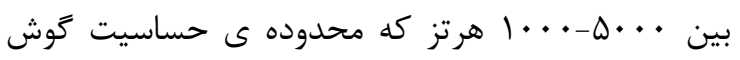

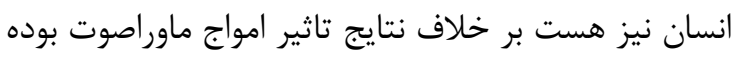

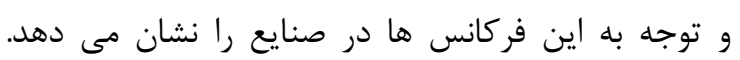
اكرجه در اين تحقيق بر اساس تقويت كننده صوتاني ساخته شده آلودحى صوتى با فر كانس هاى مختلف ايجاد

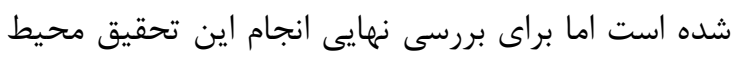

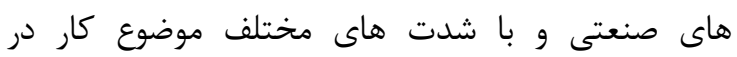

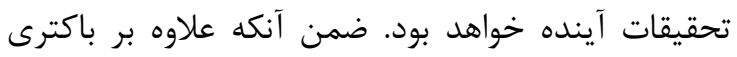

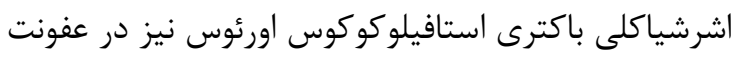
ها و آلودگى هاى محيطى تاثير دارد و و تاثير امواج صوتى آنى








\section{References}

1. Frank JR. Number of workers exposed to occupational noise. Thieme Medical Publisher; 1988; 287-98.

2. Ghajar M. A, Study of noise and effects on hearing of zamzam.Co workers. The journal of mazandaran university of medical sciences. 1996;6(13):21-25

3. Harris CM. Handbook of acoustical measurements and noise control. New York: McGraw-Hill.1991

4. NSC. Noise control: a guide for employees \& employers. National Safety council, 1989, 17(68), 118-20.

5. Falahati A, Boluri B. The effect of sine magnetic fields on growth E.coli. Journal of ShahidSadughi University ofMedical Sciences 2000; 7: 59-63. [In Persian]

6. Nascimento LFC, Botura JG, Mota RP. Glucose consume and growth of E. coli under electromagnetic fields. RevInst Med Trop St. Paulo 2003; 45: 65-67.

7. Naddeo V, Landi M, Belgiorno V, Napoli RM. Wastewater disinfection by combination of ultrasound and ultraviolet irradiation. J Hazard Mater 2009;168(2-3): 925-9.

8. Neis U, Blume T. Ultrasonic disinfection of wastewater effluents for high-quality reuse. Water SciTechnol 2003;3(4):261-7.

9. Gholami M, Dehghanifard E, Zarghampour Z, Mirzaei R, DehghaniNayeri M, Performance of Ultrasonic Process on
Removal of Fecal Indicator Bacteria of Escherichia Coli and Enterococcus Faecalis from Drinking Water, J BabolUniv Med Sci 2011; 14(1) 36-41.

10. Sayed EL. Gaafar A, Maged A S, Tohamy Y, Mona H, Stimulation and control of E-Coli by using an external low frequency magnetic field, ROMANIAN J. BIOPHYS 2006, 16, 4, 283-296

11. Su X, Zivanovic S, D'Souza DH. Inactivation of human enteric virus surrogates by high-intensity ultrasound.Foodborne Pathog Dis 2010;7(9):1055-61.

12. WHO. Guidelines for drinking-water quality. 3rd ed. Geneva: World Health Organization (WHO) 2008; pp: 521-63.

13. Antoniadis A, Poulios I, Nikolakaki E, Mantzavinos D. Sonochemical disinfection of municipal wastewater. J Hazard Mater 2007;146(3):492-5.

14. Joyce E, Phull SS, Lorimer JP, Mason TJ. The development and evaluation of ultrasound for the treatment of bacterial suspensions: A study of frequency, power and sonication time on cultured Bacillus species. UltrasonSonochem 2003;10(6):315-8.

15- Feng QL, Wu J, Chen GQ, Cui FZ, Kim TN, Kim JO. A mechanistic study of the antibacterial effect of silver ions on Escherichia coli and Staphylococcus aureus. J Biomed Mat Re 2000; 52(4): 662-68. 
Original Article

\title{
Effect of single frequency noise pollution on the growth of Escherichia coli bacteria
}

\author{
Younessi Heravi $\mathrm{MA}^{1 *}$, Hosseini $A^{2}$,Besharati $R^{3}$ \\ ${ }^{1}$ M.Sc of Biomedical engineering, Department of Basic Sciences, Medicine School North Khorasan University \\ of Medical Sciences, Bojnurd, Iran. \\ ${ }^{2}$ Student Research Committee, North Khorasan University of Medical Sciences, Bojnurd, Iran. \\ ${ }^{3}$ M.Sc of Microbiology, Department of Basic Sciences, Medicine School North Khorasan University of Medical \\ Sciences, Bojnurd, Iran
}

\begin{abstract}
*Corresponding Author:
Department of Basic Sciences, Medicine School, Shahriar St, Bojnurd North Khorasan, Iran. E-mail: a.younessi7@gmail.com
\end{abstract}

Submitted: 12 May 2013

Revised:29 May 2013

Accepted:11 June 2013

\begin{abstract}
Background \& Objective: Accompanying with industrialization, noise pollution is coming to be a serious problem in the workplace. Since some of peripheral infections have been caused by Escherichia coli bacteria, the purpose of this study was to evaluate the effect of single-frequency noise pollution on the growth of Escherichia coli.
\end{abstract}

Material \& methods: An audio amplifier was designed and constructed in order to produce sound waves of multiple 8 different frequencies. Centers of frequency were included 63.5, $125,250,500,1000,2000,4000$ and $8000 \mathrm{~Hz}$. The sound intensity was considered as well of $30 \mathrm{~dB}$. In each frequency, ten medium of E-Coli were studied. Mediums were divided into two groups and were incubated in the same conditions one group in the exposure of sound waves (experimental group) and the other without a sound wave (controls). The bacteria were incubated at $37^{\circ} \mathrm{C}$ for $24 \mathrm{~h}$. Then bacterial colonies were counted. The results of the experimental and control groups were analyzed by with MATLAB2011 and presented with t-test. Alpha level of 0.05 was considered significance.

Results: The results showed that the bacterial growth rate significantly increases in frequency of 63.5, 1000, 2000 and 4000 $\mathrm{Hz}(\mathrm{p}<0.05)$, such that bacterial growth rates also increase through the frequency increasing. Bacterial growth rate was significantly reduced in $8000 \mathrm{~Hz}(p<0.05)$. In other frequencies, the bacteria growth rate did not follow a specific pattern and their changes were not significant.

Conclusions: This study showed that single frequency noise pollution has effect on bacteria growth and its effects are increased on within the ear sensitivity. Therefore this area could provide fertile ground for the growth of bacteria, thus controlling the audio frequency is proposed in industrial environments.

Key words: noise pollution, growth rate, Escherichia coli bacteria. 